\title{
Reactional ultrasonic systems and microwave irradiation for pretreatment of agro-industrial waste to increase enzymatic activity
}

\author{
Fabiane Fernanda Czapela', Simone Kubeneck , Karina Paula Preczeski ', Caroline Dalastra ${ }^{1}$, Thamarys Scapini ${ }^{1}$, \\ Charline Bonatto ${ }^{1}$, Fábio Spitza Stefanski ${ }^{1}$, Aline Frumi Camargo ${ }^{1}$, Jessica Zanivan ${ }^{1}$, Altemir José Mossi ${ }^{1}$, \\ Gislaine Fongaro ${ }^{2}$ and Helen Treichel ${ }^{1^{*}}$ (D)
}

\begin{abstract}
Pretreatment of keratinous residues using an ultrasonic reaction system provides greater enzymatic production in less time. This is a promising technology for measuring enzyme activity and microwave processes. In the present work, an ultrasonic probe reaction system was used to evaluate the potential of swine hair pretreatment. The pretreated material was submerged with non-pretreated residues for 9 days to obtain the enzyme. Enzyme activity was measured in the extracts obtained using the ultrasonic probe, ultrasonic bath, and microwave. We also used the enzymatic concentration technique with $\mathrm{NaCl}$ and acetone. Homemade enzymatic extracts were evaluated for their ability to degrade swine hair and chicken feathers by comparing them with the activities commercial enzymes. Macrobeads gave greater energy dissipation in less time, providing greater enzyme activity (50.8 U/mL over 3 days). In terms of waste degradation, non-pretreated swine hair was more promising. The ultrasonic probe reaction system had the potential to evaluate increased enzyme activity (38.4\% relative activity) and the enzyme concentration increased activity by $53.5 \%$. The homemade enzymatic extract showed promise for degradation of keratinous residues.
\end{abstract}

Keywords: Reaction system, Keratin residues, Biotechnological processes

\section{Introduction}

Keratinous waste is generated in large quantities; managing this waste is made difficult by its resilient structure (Onifade et al. 1998; Laba et al. 2015). These residues consist of fibrous proteins such as keratins that are resistant to physical, chemical and enzymatic actions (Korniłłowicz-Kowalska and Bohacz 2011). When found in their solid state, the structure of the keratin increases its stiffness because of cysteine bonds (Barone et al.

\footnotetext{
*Correspondence: helentreichel@gmail.com

${ }^{1}$ Laboratory of Microbiology and Bioprocesses, Universidade Federal Da Fronteira Sul-UFFS, Rodovia ERS 135-Km 72, no 200, Erechim, RS 99700-970, Brazil

Full list of author information is available at the end of the article
}

2006), as well as by $\alpha$ and $\beta$-keratin chains and disulfide bonds (Onifade et al. 1998). Alpha-keratin can be found in materials such as hair, fur, nails, hooves, and animal horns, while $\beta$-keratin is present in scales, bird feathers, and beaks (Korniłłowicz-Kowalska and Bohacz 2011; Mazotto et al. 2011; Ire and Onyenama 2017).

One way to promote the degradation of these residues is via biotechnological processes, particularly degradation through the action of specific enzymes such as keratinases (Gupta and Ramnani 2006; Brandelli 2008; Brandelli et al. 2010; Gegeckas et al. 2018). Keratinases (EC 3.4.21/24/99.11) are a class of proteases that hydrolyze keratin, an advantage over other proteases (Brandelli et al. 2010; Gegeckas et al. 2018). These enzymes have applications such as biotechnology (Okoroma et al. 2012; 
Mazotto et al. 2013; Paul et al. 2014; Brandelli et al. 2015) and waste degradation (Fang et al. 2013a; Yusuf et al. 2016; Su et al. 2017; Abdel-Fattah et al. 2018; Thankaswamy et al. 2018). They can be obtained commercially or from submerged fermentation (FS) or solid-state fermentation (FES) through microorganisms (Mazotto et al. 2013) such as fungi (Kushwaha 1983; Santos et al. 1996), that are considered good producers of keratinases; they can also be isolated from keratinous waste disposal sites (Kaul and Sumbali 1997; Riffel and Brandelli 2006). When obtained in this way, they are designated "homemade" and can be used in crude or concentrated form, a technique that combines the interaction of the enzyme with salts and solvents so as to separate out interferents (Preczeski et al. 2018).

Because of the biotechnological importance of keratinases, several studies have been performed to improve the activity and to evaluate the conformational change of enzymes in general, when exposed to different reaction systems, including ultrasonic probe and bath and microwave (Ma et al. 2011; Jin et al. 2015; Mazinani et al. 2015). Simple and efficient heating technologies increase enzyme activity and conformational change ( $\mathrm{Ma}$ et al. 2011); residue pretreatment techniques using an ultrasonic probe (Azmi et al. 2018), makes the structures more accessible to microbial and enzymatic attack (Yusof and Ashokkumar 2015).

The present study aimed to evaluate the potential for pretreatment of agro-industrial residues using an ultrasonic probe and to investigate the behavior of keratinases exposed to the following reaction systems: ultrasonic probe, ultrasonic bath, and the microwave and enzymatic concentration technique. In addition to comparing the activity of homemade enzymes with commercial enzymes and finally, we applied enzymatic extracts for the degradation of keratinous residues such as swine hair and chicken feathers.

\section{Materials and methods}

\section{Keratin substrates}

Swine hair and chicken feathers were obtained from a food agroindustry in Rio Grande do Sul, Brazil. Residues were stored at $-4{ }^{\circ} \mathrm{C}$ until use. Prior to use, the residues were washed with water and detergent, and immersed in $70 \%$ alcohol for $1 \mathrm{~h}$, followed by drying at $70 \pm 2{ }^{\circ} \mathrm{C}$ for $16 \mathrm{~h}$ (adapted from Călin et al. 2017; Preczeski et al. 2020). Chicken feathers were used in the degradation tests only.

\section{Swine hair pretreatment by ultrasonic probe}

Swine hair (1 g) was treated using an ultrasonic probe, comparing the micropoint and macropoint. The variables used were power (100\%), pulse (3) and exposure time (15 min) using distilled water $(100 \mathrm{~mL})$ as a liquid medium in a $250 \mathrm{~mL}$ glass beaker (Adapted Azmi et al. 2018). The tests were conducted in triplicate. These were performed with the ECO-SONICS Ultrasonic Probe/Cell Disrupter Sonicator, $20 \mathrm{kHz}$ ultrasonic frequency and $550 \mathrm{~W}$ ultrasonic power, equipped with a 4-mm titanium micropoint and 13-mm diameter titanium macropoint. Its operation is the result of the conversion of electrical energy into mechanical energy (BIOVERA 2019).

The acoustic energy of the ultrasonic probe was calculated using the calorimetric determination method, according to Eq. 1 (Feng et al. 2011). This energy is subsequently converted into heat. The experiment was carried out in a $250 \mathrm{~mL}$ beaker containing $100 \mathrm{~mL}$ of distilled water, proceeding to the pretreatment in the ultrasonic probe with the micropoint and macropoint according to the conditions specified previously. The temperature was measured with the aid of a digital thermometer.

$$
E_{a}=m C_{p} \frac{d T}{d t} .
$$

Where: $E_{a}$ is the acoustic energy per unit of time (Power), $m$ is the mass of the sample, $C_{p}$ is the specific heat of the sample and $\frac{d T}{d t}$ is the temperature variation over a given time.

The sonicated material was filtered on filter paper and the solid fraction was subjected to a microbial load reduction process using $70 \%$ alcohol and heating at $70{ }^{\circ} \mathrm{C} \pm 2{ }^{\circ} \mathrm{C}$ for $16 \mathrm{~h}$ before starting fermentation (Adapted from Călin et al. 2017).

\section{Submerged fermentation}

Submerged fermentation was performed with swine hair. To this end, $10 \mathrm{~g} \mathrm{~L}^{-1}$ of pretreated and not pretreated ultrasonic probe residue was poured into $50 \mathrm{mM}$ Tris $\mathrm{HCl}$ buffer ( $\mathrm{pH} 8.5$ ) with the addition of $10^{6}$ spores $\mathrm{mL}^{-1}$ of Fusarium oxysporum. The fermentative medium was incubated at $150 \mathrm{rpm}$ and $28{ }^{\circ} \mathrm{C}$ for 9 days (Preczeski et al. 2020). The fungus used was isolated from soil-borne chicken feather residues and identified using the Next Generation Sequencing (NGS) method (Preczeski et al. 2020).

At the end of the fermentation, the fermented medium was filtered and the retained solid fraction was dried to quantify the degradation percentage of the agro-industrial residue, according to Eq. 2. The residues were dried in an oven at $70 \pm 2{ }^{\circ} \mathrm{C}$ for $16 \mathrm{~h}$ then they remained in a desiccator for 1 day. Subsequently, initial and final dry mass measurements (residues before and after the FS) was performed (Preczeski et al. 2020). The filtrate was used to measure keratinolytic activity and exposure in various reaction systems. Keratinolytic activity was quantified at 3, 6, and 9 days, and the percentage of residue 
degradation was quantified after 9 days (Preczeski et al. 2020).

$$
\operatorname{Degradation}(\%)=100-\left(\frac{F M * 100}{I M}\right) .
$$

Where: FM is final dry mass, and IM is initial dry mass.

\section{Keratinase assay}

Keratinolytic activity was measured using $0.013 \mathrm{~g}$ azokeratin as substrate (SIGMA-ALDRICH K8500 $\alpha$-K), $3.2 \mathrm{~mL}$ $50 \mathrm{mM}$ Tris $\mathrm{HCl}$ buffer $(\mathrm{pH} 8.5)$ and $0.8 \mathrm{~mL}$ enzyme extract. The reaction took place in an ultra-thermostatic bath at $50{ }^{\circ} \mathrm{C}$ for $1 \mathrm{~h}$, after which $0.8 \mathrm{~mL}$ of $10 \%$ trichloroacetic acid (TCA) was added to stop the reaction, and was read at $595 \mathrm{~nm}$ in a spectrophotometer (Adapted from Bressollier et al. 1999).

One unit of keratinase activity was defined as the amount of enzyme required to produce a 0.01 absorbance increase under the described assay conditions (Bressollier et al. 1999). Enzyme activity was determined before and after exposure to reaction systems. Relative activity (\%) was also calculated for activity increment purposes, according to Eq. 3.

$$
\text { Relative activity }(\%)=\left(\frac{\text { Final activity }- \text { Initial activity }}{\text { Initial activity }}\right) * 100 .
$$

Where: Final activity is enzyme extract activity after exposure to reaction systems, and Initial activity is activity of crude enzyme extract before exposure to reaction systems.

\section{Enzyme activity increase Exposure of enzyme extracts to reaction systems}

Enzymatic extracts produced using swine hair as substrate pretreated with ultrasonic probe with macropoint and not pretreated were exposed to ultrasonic probe, ultrasonic bath and microwave using the experimental design methodology, aiming to evaluate the behavior of the enzymes. Each reaction system was evaluated using central composite design (CCD) based on previously defined independent variables, according to reaction interest and system possibilities. The response variable was relative activity (\%), resulting from the variation between keratinolytic activities of the extract before and after exposure to reaction systems (Eq. 2).

Ultrasonic probe A $20 \mathrm{~mL}$ aliquot of the crude enzyme extract was exposed to the ECO-SONICS Cell Disruptor Probe $(20 \mathrm{kHz}$ and $550 \mathrm{~W})$ equipped with a $4-\mathrm{mm}$ diameter titanium micropoint. The behavior of keratinases was evaluated under different conditions of exposure time (2-10 $\mathrm{min}$ ), power (40\% to $80 \%$ ) and pulse (1 to 3 ) following experimental design CCD $2^{3}$ (ECO-SONICS).

Ultrasonic bath In this reaction system, $2 \mathrm{~mL}$ aliquots of the crude enzyme extract were exposed to the ultrasonic bath, varying the temperature $\left({ }^{\circ} \mathrm{C}\right)$, the power (\%) and the exposure time (min) of the enzyme extract according to experimental design. The equipment used was the UNIQUE Ultrasonic Washer, model USC-1800 A, frequency US $40 \mathrm{kHz}$ and maximum power of $137 \mathrm{~W}$ $\left(0.42 \mathrm{~W} \mathrm{~cm}^{-2}\right)$. The tests were performed with ultrasonic bath temperature ranging from 30 to $80{ }^{\circ} \mathrm{C}$, ultrasonic power ranging from 0 to $100 \%$ and with exposure time of 10 to $40 \mathrm{~min}$, following experimental design (Adapted from Golunski et al. 2017; Adapted from Mulinari et al. 2017).

Microwave Aliquots of $3 \mathrm{~mL}$ of crude enzyme extract were exposed to microwave, varying conditions according to experimental design. Exposure of the enzyme to microwaves was evaluated in the time range of 5 to $15 \mathrm{~min}$, using temperatures between 30 and $80{ }^{\circ} \mathrm{C}$, according to the methodology described by Mazinani et al. (2015) and adapted from Golunski et al. (2017).

The equipment used was the ANTON PAAR Monowave 100 Microwave Reactor which has unpulsed $500 \mathrm{~W}$ output power (ANTON PAAR).

\section{Enzymatic concentration}

To test the most economically viable enzymatic activity increment methods, the enzyme concentration technique was performed. Enzyme extracts obtained from the fermentation process were concentrated using $0.5 \mathrm{~mol} \mathrm{~L}^{-1} \mathrm{NaCl}$ and $50 \%\left(\mathrm{v} \mathrm{v}^{-1}\right)$ acetone. The tests were performed in an ice bath at $4{ }^{\circ} \mathrm{C}$. After centrifugation at $9500 \times g, 4{ }^{\circ} \mathrm{C}$ and $20 \mathrm{~min}$, the supernatant phase was discarded and the precipitate was resuspended with $50 \mathrm{mM}$ Tris $\mathrm{HCl}$ buffer ( $\mathrm{pH}$ 8.5) (Preczeski et al. 2018).

The concentrated enzymatic extract (homemade) was exposed to reaction systems under the conditions of greatest activity increase in experimental designs and applied to the degradation of swine hair and chicken feathers, aiming to evaluate the degradation potential of keratinous residues. 


\section{Commercial enzymes and reaction systems}

The activity of the homemade enzyme extract was compared with that of the commercial enzyme K4519 SIGMA with initial enzymatic activity of $2812.5 \mathrm{U}$ $\mathrm{mL}^{-1}$. K4519 SIGMA keratinase was diluted in $5 \mathrm{mM}$ phosphate buffer ( $\mathrm{pH}$ 7.0) (SIGMA-ALDRICH). The enzyme was exposed to the optimal enzymatic increment conditions obtained in the experimental designs for the ultrasonic probe, ultrasonic bath and microwave and was subsequently used for the degradation of keratinous residues.

\section{Evaluation of keratin residue degradation}

Swine hair and chicken feather degradation was evaluated using crude and concentrated enzyme extracts, both with and without exposure to reaction systems. The degradation potential of agro-industrial residues was also evaluated using the commercial enzyme extract K4519 SIGMA before and after exposure to reaction systems.

One whole feather or $0.1 \mathrm{~g}$ of swine hair was used for each $8 \mathrm{~mL}$ of enzyme extract. Assays were incubated at $28{ }^{\circ} \mathrm{C}$ for 28 days (Scott and Untereiner 2004), and the result was evaluated based on visible residue degradation.

\section{Characterization of homemade keratinase enzymes}

For the purpose of obtaining the optimal $\mathrm{pH}$ and temperature of the enzyme used, a characterization was carried out evaluating different $\mathrm{pH}$ conditions, ranging from 5 to 9 and temperature, from $37^{\circ} \mathrm{C}$ to $70{ }^{\circ} \mathrm{C}$. The buffers used were: $50 \mathrm{mM}$ citrate buffer $\mathrm{pH} 5.0$ and 5.7; $50 \mathrm{mM}$ sodium phosphate buffer $\mathrm{pH} 7.1, \mathrm{pH} 8.4$ and $\mathrm{pH} 9.0 ; 50 \mathrm{mM}$ Tris $\mathrm{HCl}$ buffer $\mathrm{pH} 8.5$ (SIGMAALDRICH). The characterization was carried out in an ultra-thermostatic bath and the activity measurement followed that specified in item 2.4.

\section{Statistical analysis}

The experiments were statistically evaluated using CCD and the results of the enzymatic activity were analyzed using Protimiza Experimental Design software (Rodrigues and Iemma, 2014), using 95\% confidence analysis of variance $(p<0.05)$. Results were presented as mean \pm standard deviation of triplicate experiments. Statistical differences between data sets were verified using ANOVA and Tukey Test (Fegade et al. 2013).

\section{Results and discussion}

\section{Swine hair pretreatment by ultrasonic probe}

The amount of energy required for the pretreatment of swine hair with the ultrasonic probe was determined
Table 1 Initial and final temperature measurement for the ultrasound probe's micropoint and macropoint to determine the amount of energy required for the pretreatment of swine hair

\begin{tabular}{llllll}
\hline Assays & Micropoint & & & Macropoint & \\
\cline { 2 - 3 } \cline { 5 - 6 } $\begin{array}{l}\text { Initial } \\
\text { temperature }\end{array}$ & $\begin{array}{l}\text { Final } \\
\text { temperature }\end{array}$ & $\begin{array}{l}\text { Initial } \\
\text { temperature }\end{array}$ & $\begin{array}{l}\text { Final } \\
\text { temperature }\end{array}$ \\
\hline $16.1 \pm 0.2^{\circ} \mathrm{C}$ & $26.5 \pm 1.2^{\circ} \mathrm{C}$ & & $19.5 \pm 0.3^{\circ} \mathrm{C}$ & $53.3 \pm 2.4^{\circ} \mathrm{C}$ \\
\hline
\end{tabular}

Table 2 Keratinolytic activity after pretreatment in an ultrasonic probe and without pretreatment at 3, 6 and 9 days, as well as the percentage of degradation obtained at the end of the fermentation process

\begin{tabular}{|c|c|c|c|c|}
\hline \multirow[t]{2}{*}{ Swine hair } & \multicolumn{3}{|c|}{ Enzymatic activity $\left(\mathrm{U} \mathrm{mL}^{-1}\right)$} & \multirow{2}{*}{$\begin{array}{l}\text { Degradation } \\
\text { (\%) }\end{array}$} \\
\hline & 3 days & 6 days & 9 days & \\
\hline \multicolumn{5}{|c|}{ Pretreatment by ultrasonic probe } \\
\hline Micropoint & $38.8 \pm 5.3^{\mathrm{a}}$ & $81.0 \pm 5.2^{\mathrm{a}}$ & $55.7 \pm 3.0^{\mathrm{a}}$ & $31.8 \pm 1.1^{\mathrm{a}}$ \\
\hline Macropoint & $50.8 \pm 5.3^{b}$ & $39.5 \pm 4.8^{b}$ & $43.8 \pm 1.1^{b}$ & $45.5 \pm 0.8^{b}$ \\
\hline $\begin{array}{l}\text { Without pre- } \\
\text { treatment }\end{array}$ & $25.0 \pm 5.6^{a}$ & $82.2 \pm 9.4^{a}$ & $75.2 \pm 3.2^{c}$ & $36.3 \pm 4.0^{\mathrm{a}}$ \\
\hline
\end{tabular}

Equal lowercase letters do not differ from each other by the Tukey test on the column

by the method of calorimetric determination for the micropoint and for the macropoint and calculated using Eq. 1. Table 1 shows the initial temperature values and end for each tip used.

Afterwards, the acoustic energy of the ultrasonic probe was calculated, obtaining the values of $E_{a}=4.35 \mathrm{~kJ}$ and $E_{a}=14.2 \mathrm{~kJ}$ for the micropoint and macropoint respectively. It is seen that when the macropoint is used, the amount of energy required is higher, consequently, causing a greater increase in temperature. Most of the effects caused by the ultrasonic probe occur through the cavitation process, which is nothing more than the collapse of bubbles in a medium when they reach a certain temperature (Kuijpers et al. 2002).

The fermentative process to obtain the enzymatic extract was performed using swine hair as the substrate that had been pretreated with or without the ultrasonic probe. Enzymatic activities and degradation percentages were evaluated (Table 2).

The keratinolytic activity obtained on the third day of the fermentation in the swine hair pretreated with the ultrasonic probe macropoint was $50.8 \pm 5.3 \mathrm{U} \mathrm{mL}^{-1}$. From this result, it can be inferred that the greater energy dissipation caused by the macropoint resulted in more relevant data of enzymatic activity, because it has a larger diameter than that of the micropoint, which achieved 
enzymatic activity $\left(38.8 \pm 5.3 \mathrm{U} \mathrm{mL}^{-1}\right)$ similar to that obtained with the crude residue $\left(25.0 \pm 5.6 \mathrm{U} \mathrm{mL}^{-1}\right)$.

We found that the micropoint did not have the same impact on structure in terms of enzymatic activity for the 3rd day, because the ultrasonic system can be influenced by several factors, including energy dissipation, ultrasonic intensity, temperature, exposure time, and diameter (Lippert et al. 2018), all of which may have resulted in lower erosion efficiency of the structure when using the micropoint than when using the macropoint.

The highest keratinolytic activity was observed for swine hair without pretreatment and with micropoint pretreatment at 6 days of fermentation: $82.2 \pm 9.4 \mathrm{U} \mathrm{mL}^{-1}$ and $81.0 \pm 5.2 \mathrm{U} \mathrm{mL}^{-1}$, respectively. Regarding the degradation percentage, the highest degradation occurred in the pretreatment test with ultrasonic probe with macropoint $(45.5 \% \pm 0.8 \%)$, and it can be inferred that the abrasion and erosion in the structure of swine hair, which resulted in the highest enzymatic activity in 3days for the same assay, also presented the highest dissolution of structural chains that make up the residue in question, resulting in the largest mass loss in this experiment.

The ultrasonic probe increases reaction rates, especially hydrolysis processes (Zou et al. 2016). Ultrasonic systems facilitate structural degradation via propagation of ultrasonic waves that cause bubble cavitation, causing temperature rise, favoring the formation of rapidly reacting radicals (Wang 1981; Manasseh et al. 2010; Yusof and Ashokkumar 2015), improving the enzymatic attack on the substrate (Yang and Fang 2015). The cavitation process is the fundamental factor for the efficiency of ultrasound pretreatment, because the explosion of bubbles near the surface of the material causes abrasion and erosion, reducing the surface area of the structure and, consequently, improving the processes. hydrolysis and enzyme production (McClements 1995; Barton et al. 1996; Mason et al. 2011). Similar observations were reported by Jin et al. (2015), who verified changes in the kinetic characteristics between proteins and substrates in ultrasonic systems, observing the increase in hydrolysis rate, improving the affinity between enzyme and substrate.

Pretreatment with an ultrasonic probe can be considered viable with the use of the macropoint when the objective of the process is enzyme production in shorter times. Visualizing the system in search of an efficient residue degradation and relevant enzymatic activities, the system with swine hair without pretreatment presented greater viability in relation to the higher enzymatic productions of the other experiments, considering that in 6 days there was an enzymatic production of approximately $38 \%$ greater than with the pretreated macropoint residue in 3days, and only a $10 \%$ difference in residue degradation from the same assay. Comparing the data from the pretreated residue with micropoint, there was no significant difference between the data, suggesting that using the residue without pretreatment is more promising, in addition to ensuring lower energy expenditure.

\section{Enzyme activity increase \\ Exposure of enzyme extracts to reaction systems}

Exposure to reaction systems was performed to evaluate the behavior of keratinases enzymes in various reaction systems. The ultrasonic probe, ultrasonic bath and microwave were evaluated. Two enzyme extracts were exposed to the reaction systems: (a) enzymatic extract from FS carried out with swine hair pretreated with ultrasonic probe with macropoint; (b) enzymatic extract from FS carried out with swine hair without pretreatment.

Ultrasonic probe The enzymatic extracts were exposed to an ultrasonic probe using the micropoint. This was studied based on an experimental matrix (Table 3), which presents the results obtained for the independent variables of exposure time, power and pulse, and evaluated relative activity in response.

For the enzymatic extract produced from swine hair pretreated using the ultrasonic probe, up to $23.3 \%$ were observed in test 7 , corresponding to the shortest time evaluated ( $2 \mathrm{~min}$ ) (Table 3$)$. When subjected to effects analysis, there was a significant negative effect only of the time variable: the shorter the exposure time to the ultrasonic probe, the greater the keratinolytic activity. Power and pulse were not significant.

For the enzymatic extracts obtained with swine hair that was not pretreated, more promising increments were observed. Table 3 shows that test 1 showed the largest increase in keratinolytic activity in relation to crude enzyme extract, i.e., $38.4 \%$ increase in enzymatic activity. The analysis of the effects of the variables on keratinolytic activity showed that only there was only a significant negative effect on the time variable: the longer the exposure time to the ultrasonic probe, the lower the keratinolytic activity achieved. As before, power and pulse were not significant in the process. In both cases studied, the statistical model was not validated due to Fcal $<$ Ftab.

The largest increases in activity occurred in the shortest exposure time evaluated ( $2 \mathrm{~min})$, corroborating the statistical analysis. Ultrasonic systems are responsible for generating waves that propagate through a liquid, which collapse at high temperatures. This phenomenon is called cavitation. The shear force resulting from the explosion of these microbubbles causes rapid heat and mass transfer, promoting increased enzymatic activity (Jin et al. 2015). Thus, the increase in activity may be a result of the shorter exposure time to the ultrasonic probe that 
Table 3 Experimental planning matrix (real and coded values) and relative activity results (\%) for the conditions evaluated in the reaction system ultrasonic probe with enzymatic extracts produced from swine hair pretreated by ultrasonic probe and without pretreatment

\begin{tabular}{|c|c|c|c|c|c|}
\hline \multirow[t]{2}{*}{ Assays } & \multicolumn{3}{|c|}{ Ultrasonic probe } & \multicolumn{2}{|l|}{ Relative activity (\%) } \\
\hline & Time (min) & Power (\%) & Pulse & $\begin{array}{l}\text { Pretreatment by ultrasonic } \\
\text { probe }\end{array}$ & Without pretreatment \\
\hline 1 & $-1(2)$ & $-1(40)$ & $-1(1)$ & 11.3 & 38.4 \\
\hline 2 & $+1(10)$ & $-1(40)$ & $-1(1)$ & 0.0 & 1.4 \\
\hline 3 & $-1(2)$ & $+1(80)$ & $-1(1)$ & 2.7 & 16.3 \\
\hline 4 & $+1(10)$ & $+1(80)$ & $-1(1)$ & 0.0 & 9.1 \\
\hline 5 & $-1(2)$ & $-1(40)$ & $+1(3)$ & 0.0 & 21.1 \\
\hline 6 & $+1(10)$ & $-1(40)$ & $+1(3)$ & 0.0 & 0.0 \\
\hline 7 & $-1(2)$ & $+1(80)$ & $+1(3)$ & 23.3 & 25.2 \\
\hline 8 & $+1(10)$ & $+1(80)$ & $+1(3)$ & 0.0 & 10.3 \\
\hline 9 & $0(6)$ & $0(60)$ & $0(2)$ & 0.0 & 0.0 \\
\hline 10 & $0(6)$ & $0(60)$ & $0(2)$ & 0.0 & 3.0 \\
\hline 11 & $0(6)$ & $0(60)$ & $0(2)$ & 0.0 & 0.0 \\
\hline 12 & $0(6)$ & $0(60)$ & $0(2)$ & 0.0 & 0.0 \\
\hline \multicolumn{4}{|c|}{ Enzymatic extract obtained after FS without exposure to reaction systems } & $75.0 \cup \mathrm{mL}^{-1}$ & $124.3 \cup \mathrm{mL}^{-1}$ \\
\hline
\end{tabular}

favors the decomposition of interfering molecules and the change in enzymatic specificity, making enzymes more easily accessible to the reaction and consequently increasing their activity, providing an ideal environment for the reaction between enzyme and substrate (McClements 1995; Jin et al. 2015). The enzyme also remains more regular and flexible because thermodynamic parameters such as $\mathrm{Ea}, \Delta \mathrm{H}$, and $\Delta \mathrm{S}$ are reduced with the use of ultrasound, causing an improvement in its activity and improving the operational stability of enzymes (Ma et al. 2011; Wang et al. 2013).

In assays where the exposure time was longer (from 6 to $10 \mathrm{~min}$ ), the activity was lower and, in some cases, lower than the activity obtained in the enzyme extract without exposure to the ultrasonic probe, possibly due to the enzymatic denaturation caused by the longer exposure time to the ultrasonic probe (Kapturowska et al. 2012). Denaturation of enzymes can occur due to excess pressure, temperature or even shear force generated during the cavitation phenomenon in the ultrasonic system (Grintsevich et al. 2001; Potapovich et al. 2003).

It is important to note that the use of ultrasonic systems is efficient in reducing reaction time, promoting increased enzymatic activity in many cases. On the other hand, depending on the conditions studied, there may be an enzymatic denaturation and consequently a decrease in enzyme activity.

Ultrasonic bath The greatest increase in enzymatic activity obtained for the ultrasonic bath occurred in the enzymatic extract from swine hair pretreated with ultrasonic probe (30.2\%), with a temperature of $80{ }^{\circ} \mathrm{C}$ during $40 \mathrm{~min}$ of exposure and $0 \%$ power, corresponding to test 6 (Table 4 ).

Analysis of effects on keratinolytic activity showed that temperature and power were important. The temperature variable had significant positive effects; that is, the higher the temperature, the higher the keratinolytic activity. The power variable affected the enzyme activity negatively; the lower the power, the higher the activity. Time had no influence on enzymatic activity. Because Fcal $>$ Ftab, the statistical model was validated.

For enzymatic extract produced from swine hair without pretreatment, only test 3 , corresponding to a temperature of $30{ }^{\circ} \mathrm{C}$ during $10 \mathrm{~min}$ and $100 \%$ power, provided an increase of keratinolytic activity in relation to the crude enzyme, which was $5.9 \%$ (Table 4). However, when the results were subjected to effects analysis, no variable was found to be significant. For this enzyme extract studied, the model was not statistically validated due to $\mathrm{Fcal}<\mathrm{Ftab}$.

In the enzymatic extracts evaluated, different behaviors of the enzyme regarding temperature were observed. For the pretreated residues, the enzyme extract increased the activity at a temperature of $80^{\circ} \mathrm{C}$ and for the untreated residues, the only activity increase was at the temperature of $30{ }^{\circ} \mathrm{C}$, the mildest within the study range. This shows that the enzymes produced during submerged fermentation with pretreated and untreated residues are different in the mode of action compared to the ultrasonic bath reaction system. 
Table 4 Experimental planning matrix (real and coded values) and relative activity results (\%) for the conditions evaluated in the reaction system ultrasonic bath with enzymatic extracts produced from swine hair pretreated and nonpretreated with an ultrasonic probe

\begin{tabular}{|c|c|c|c|c|c|}
\hline \multirow[t]{2}{*}{ Assays } & \multicolumn{3}{|l|}{ Ultrasonic Bath } & \multicolumn{2}{|l|}{ Relative activity (\%) } \\
\hline & Temperature $\left({ }^{\circ} \mathrm{C}\right)$ & Power (\%) & Time $(\min )$ & $\begin{array}{l}\text { Pretreatment } \\
\text { by ultrasonic probe }\end{array}$ & Without pretreatment \\
\hline 1 & $-1(30)$ & $-1(0)$ & $-1(10)$ & 0.0 & 0.0 \\
\hline 2 & $+1(80)$ & $-1(0)$ & $-1(10)$ & 9.4 & 0.0 \\
\hline 3 & $-1(30)$ & $+1(100)$ & $-1(10)$ & 0.0 & 5.9 \\
\hline 4 & $+1(80)$ & $+1(100)$ & $-1(10)$ & 0.0 & 0.0 \\
\hline 5 & $-1(30)$ & $-1(0)$ & $+1(40)$ & 0.0 & 0.0 \\
\hline 6 & $+1(80)$ & $-1(0)$ & $+1(40)$ & 30.2 & 0.0 \\
\hline 7 & $-1(30)$ & $+1(100)$ & $+1(40)$ & 0.0 & 0.0 \\
\hline 8 & $+1(80)$ & $+1(100)$ & $+1(40)$ & 0.0 & 0.0 \\
\hline 9 & $0(55)$ & $0(50)$ & $0(25)$ & 0.0 & 0.0 \\
\hline 10 & $0(55)$ & $0(50)$ & $0(25)$ & 0.0 & 0.0 \\
\hline 11 & $0(55)$ & $0(50)$ & $0(25)$ & 0.0 & 0.0 \\
\hline 12 & $0(55)$ & $0(50)$ & $0(25)$ & 0.0 & 0.0 \\
\hline \multicolumn{4}{|c|}{ Enzymatic extract obtained after FS without exposure to reaction systems } & $79.5 \cup \mathrm{mL}^{-1}$ & $118.5 \mathrm{U} \mathrm{mL}^{-1}$ \\
\hline
\end{tabular}

The ideal temperature range for keratinases is between 30 and $80{ }^{\circ} \mathrm{C}$, which may vary according to the microorganism that is used for the production of the enzyme, according to (Kothari et al. 2017). Another fact that determines the term stability of the enzyme is the time of exposure to that temperature. The optimum temperature can also vary depending on the source and origin of the isolated microorganism (Brandelli et al. 2010).

The behavior observed for ultrasonic bath may be related to the synergistic effect of ultrasonic waves with temperature. Several studies show increased activity of enzymes exposed to ultrasonic bath (Leaes et al. 2013; Mulinari et al. 2017). According to the literature, temperature considerably influences the increase or decrease of enzymatic activity. With a rise in temperature the activity may be increased, but depending on the structure of the enzyme, if there is a very significant rise in temperature, denaturation may occur (Resa et al. 2009). This behavior was described in the studies by Wang et al. (2011) and Ovsianko et al. (2005), where enzymatic denaturation occurred due to the effect of ultrasonic sonication causing an increase in temperature, also stimulating the effect of cavitation.

Ultrasonic bath alters the behavior of exposed enzymes. Thus, the use of ultrasonic systems can promote increases in enzymatic activity, possibly due to conformational changes in protein structure, in addition to considerably reducing the reaction time (Leaes et al. 2013) and also the decrease in activity by denaturing (Resa et al. 2009).
Microwave For the enzymatic extract produced from swine hair pretreated using the ultrasonic probe, test 2 showed an increase of activity, $15.1 \%$ at $80{ }^{\circ} \mathrm{C}$ for $5 \mathrm{~min}$ (Table 5). Performing statistical analysis, we noted that the temperature variable was significantly positive: the higher the temperature, the higher the keratinolytic activity achieved. Time had no influence on enzymatic activity. The model was statistically validated by Fcal $>$ Ftab.

For the enzymatic extract obtained from swine hair without pretreatment, we found that no assay showed an increase of keratinolytic activity (Table 5). However, performing the statistical analysis, we noted that the time variable was significantly negative; that is, the longer the microwave exposure time, the lower the keratinolytic activity achieved. The temperature had no influence on enzymatic activity.

The increase in activity obtained for enzymatic extract produced from swine hair pretreated with ultrasonic probe was because the microwaves provided an increase in enzymatic activity and an increase in reaction efficiency due to instantaneous overheating. Causing tremendous agitation of molecules that induces an increase in energy collisions, also increasing reaction and conversion rates (Ma et al. 2011; Mazinani et al. 2015).

The mechanism of microwave operation occurs by the interaction of the electromagnetic field with matter. This causes a movement of ions, which in turn cause heat generation by two mechanisms, dipole rotation and ion conduction. In chemical reactions, microwaves cause molecular friction due to the polarization of molecules. This process is responsible for increasing the friction of 
Table 5 Experimental planning matrix (real and coded values) and relative activity results (\%) for the conditions evaluated in the reaction system by microwave irradiation with enzymatic extracts produced from swine hair pretreated and non-pretreated with an ultrasonic probe

\begin{tabular}{|c|c|c|c|c|}
\hline \multirow[t]{2}{*}{ Assays } & \multicolumn{2}{|l|}{ Microwave } & \multicolumn{2}{|l|}{ Relative Activity (\%) } \\
\hline & Temperature $\left({ }^{\circ} \mathrm{C}\right)$ & Time $(\min )$ & $\begin{array}{l}\text { Pretreatment by ultrasonic } \\
\text { probe }\end{array}$ & Without pretreatment \\
\hline 1 & $-1(30)$ & $-1(5)$ & 0.0 & 0.0 \\
\hline 2 & $+1(80)$ & $-1(5)$ & 15.1 & 0.0 \\
\hline 3 & $-1(30)$ & $+1(15)$ & 0.0 & 0.0 \\
\hline 4 & $+1(80)$ & $+1(15)$ & 8.8 & 0.0 \\
\hline 5 & $0(55)$ & $0(10)$ & 0.0 & 0.0 \\
\hline 6 & $0(55)$ & $0(10)$ & 0.0 & 0.0 \\
\hline 7 & $0(55)$ & $0(10)$ & 0.0 & 0.0 \\
\hline 8 & $0(55)$ & $0(10)$ & 0.0 & 0.0 \\
\hline \multicolumn{3}{|c|}{ Enzymatic extract obtained after FS without exposure to reaction systems } & $79.5 \mathrm{U} \mathrm{mL}^{-1}$ & $128.8 \mathrm{U} \mathrm{mL}^{-1}$ \\
\hline
\end{tabular}

these molecules, consequently increasing the temperature and the reaction rate (Lopes et al. 2015). In this manner, microwave irradiation can cause conformational changes in the exposed structure, leading to increased enzyme activity or even damage such as enzymatic denaturation (Leonelli and Mason 2010; Lopes et al. 2015; Mazinani et al. 2015).

Some authors point out that the use of microwaves can cause changes in thermodynamic properties, providing increased enzymatic activity (Mazinani et al. 2015; Golunski et al. 2017). These findings suggest that conformational changes in the structure of enzymes occur when exposed to microwaves, possibly due to cleavages that occur during the process and the formation of hot spots by instant heating.

On the other hand, high temperatures and exposure times cause enzymatic denaturation. Possibly this occurred in the assays with enzymatic extract produced from untreated swine hair, where mild temperatures of $30{ }^{\circ} \mathrm{C}$ were sufficient to cause decreased enzyme activity.

Temperature is one of the factors that most influence the behavior of enzymes exposed to microwave irradiation. This causes collisions between molecules to increase, and this causes an increase in energy, causing faster reaction rates. However, at very high temperatures, the reaction rate is reduced due to the denaturation of enzymes, caused by heat breakage and also the breakdown of ionic and hydrogen bonds, stabilizing the protein structure (Yadav and Borkar 2009; Khan and Rathod 2018).

Larger increments of enzymatic activity Given the results obtained for the three reaction systems evaluated, the ultrasonic probe showed greater potential for increased enzymatic activity compared to the other reaction systems (Fig. 1).

The largest increase was obtained using the ultrasonic probe (38.4\%) with the enzymatic extract produced from swine hair without pretreatment. Ultrasonic systems also showed good results of increased enzymatic activity for the enzymatic extract produced from swine hair pretreated by ultrasonic probe, with the increment values being $23.3 \%$ for ultrasonic probe and $30.2 \%$ for ultrasonic bath. In addition, these values were reached under mild conditions of time, power and pulse, making the process more viable.

\section{Enzymatic concentration}

The enzyme concentration technique was performed to verify the possibility of increasing enzymatic activity from an economically viable and simple operation method. Enzyme extracts produced from swine hair without pretreatment were used and the enzyme concentration technique was performed in the presence of $\mathrm{NaCl}$ and acetone.

The homemade extract showed an enzymatic activity of $159.3 \mathrm{U} \mathrm{mL}^{-1}$ after the concentration technique, increasing the activity value by $53.5 \%$ when compared to the crude enzyme extract $\left(103.8 \mathrm{U} \mathrm{mL}^{-1}\right)$. The concentrated enzymatic extract (homemade) was exposed to reaction systems under the conditions of greatest activity increase in experimental designs, where it presented stability against the ultrasonic probe, ultrasonic bath and microwave, possibly due to the absence of interferents that were separated during enzymatic concentration.

After exposure, the concentrated enzymatic extract (homemade) was applied in the degradation of swine hair and chicken feathers, aiming to evaluate the degradation potential of keratinous residues. 


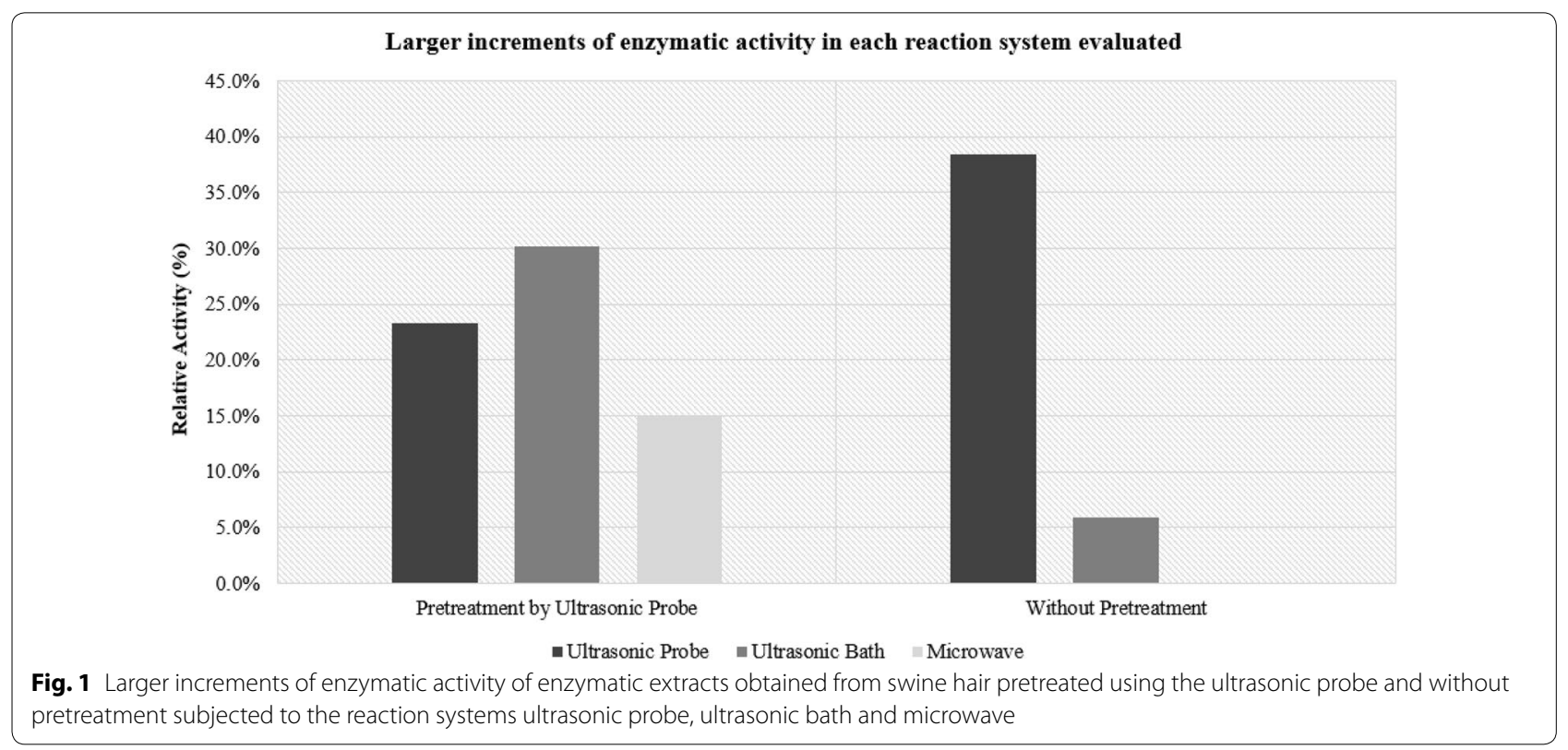

\section{Commercial enzymes and reaction systems}

The commercial enzyme K4519 SIGMA was exposed to ultrasonic probe, ultrasonic bath and microwave under the conditions of higher relative activity of homemade enzyme, to compare with the obtained data.

The enzyme K4519 SIGMA keratinase had initial activity of $2812.5 \mathrm{U} \mathrm{mL}^{-1}$. When subjected to an ultrasonic probe and bath, it showed an $11.1 \%$ increase in enzymatic activity. In microwave irradiation, there was a reduction in activity. There was high stability because it is a highly pure enzyme, with little variation when subjected to reaction systems. The activity increase observed for the enzyme K4519 SIGMA keratinase was smaller than that obtained for the homemade enzyme when subjected to ultrasonic probe (38.4\%). This behavior is expected because it is a pure enzyme with high stability.

It should be noted that the production of the homemade enzyme is low-cost because it uses a highly available residue, being an inhomogeneous residue with large variations, in addition to the fact of disposal problems secondary to difficult degradation. The produced enzyme gave good values of enzymatic activity and activity increases when subjected to reaction systems, becoming competitive against commercial enzymes.

\section{Evaluation of keratin residue degradation}

Crude and concentrated enzymatic extracts (homemade) without and with exposure to reaction systems were evaluated for degradation potential of keratinous residues. We also compared enzymatic extract with commercial enzyme K4519 SIGMA. Enzyme extracts were incubated at $28{ }^{\circ} \mathrm{C}$ for 28 days and the result was presented based on visible residue degradation and enzymatic activity.

We found that, for the crude enzyme extract and after exposure to reaction systems, the values for keratinolytic activity of the assays containing swine hair and chicken feathers showed small decreases in relation to the initial value for enzymatic activity over the 28 days, however, remaining stable over time, suggesting that the enzyme was active and showing very promising enzyme activity. For the enzyme extract in concentrated form and after exposure to reaction systems, significant increases in keratinolytic activity were observed over the 28 days of study (Table 6).

Almost total degradation of chicken feathers was observed in the crude enzyme extract and enzyme extracts after exposure to reaction systems (Fig. 2), while for swine hair, there was no degradation in any of the enzyme extracts evaluated. Possibly the enzyme could not access the resistant structure of swine hair. One factor that may explain the ease with which chicken feathers were degraded is the less rigid structure compared to swine hair. Because they are part of the keratin family, swine hair exhibits a structure that is extremely resistant to physical, chemical and also enzymatic actions (Choinska-Pulit et al. 2019).

The degradation potential of chicken feathers containing the commercial enzyme extract K4519 SIGMA was also evaluated. We found that, during the 28 days of incubation, the commercial enzyme was not able 
Table 6 Measure of keratinolytic activity at initial time and after 28 days for homemade enzymatic extract crude and concentrated and enzymatic extracts after exposure to ultrasonic reaction systems and microwave irradiation containing swine hair and chicken feathers

\begin{tabular}{|c|c|c|c|c|c|}
\hline \multirow[t]{3}{*}{ Crude } & \multirow{3}{*}{$\begin{array}{l}\text { Enzyme extracts } \\
\text { (homemade) } \\
\text { Assays }\end{array}$} & \multicolumn{2}{|c|}{ Swine hair } & \multicolumn{2}{|c|}{ Chicken feathers } \\
\hline & & $0^{\circ}$ day & $28^{\circ}$ day & $0^{\circ}$ day & $28^{\circ}$ day \\
\hline & & \multicolumn{2}{|c|}{$\begin{array}{l}\text { Enzymatic activity (U } \\
\mathrm{mL}^{-1} \text { ) }\end{array}$} & \multicolumn{2}{|c|}{$\begin{array}{l}\text { Enzymatic activity (U } \\
\mathrm{mL}^{-1} \text { ) }\end{array}$} \\
\hline Ultrasonic Probe & & 172.0 & 137.0 & 172.0 & 133.0 \\
\hline Ultrasonic bath & & 153.0 & 124.0 & 153.0 & 115.5 \\
\hline Microwave & & 96.0 & 106.5 & 96.0 & 141.0 \\
\hline Crude extract & & 171.0 & 151.5 & 171.0 & 121.5 \\
\hline \multirow[t]{3}{*}{ Concentrated } & Enzyme extracts & \multicolumn{2}{|c|}{ Swine hair } & \multicolumn{2}{|c|}{ Chicken feathers } \\
\hline & Assays & $0^{\circ}$ day & $28^{\circ}$ day & $0^{\circ}$ day & $28^{\circ}$ day \\
\hline & & \multicolumn{2}{|c|}{$\begin{array}{l}\text { Enzymatic Activity (U } \\
\mathrm{mL}^{-1} \text { ) }\end{array}$} & \multicolumn{2}{|c|}{$\begin{array}{l}\text { Enzymatic Activity (U } \\
\mathrm{mL}^{-1} \text { ) }\end{array}$} \\
\hline \multicolumn{2}{|l|}{ Ultrasonic probe } & 159.5 & 231.0 & 159.5 & 192.5 \\
\hline \multicolumn{2}{|l|}{ Ultrasonic bath } & 141.8 & 202.0 & 141.8 & 181.5 \\
\hline \multicolumn{2}{|l|}{ Microwave } & 149.0 & 229.5 & 149.0 & 191.5 \\
\hline \multicolumn{2}{|l|}{ Crude extract } & 103.8 & - & 103.8 & - \\
\hline \multicolumn{2}{|l|}{ Concentrated extract } & 159.3 & - & 159.3 & - \\
\hline
\end{tabular}

to degrade the chicken feathers, thereby favoring the homemade enzyme extract (Fig. 2).

The results obtained for the degradation test containing the homemade extracts in crude form and after exposure to the reaction systems are promising as evidenced by the degradation potential on keratinous residues. The commercial enzyme K4519 SIGMA is expensive, highly

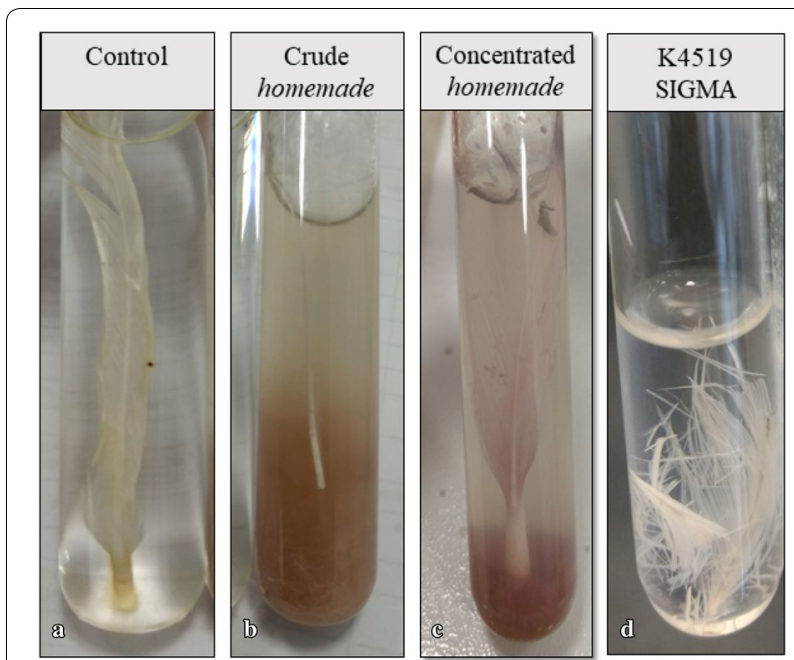

Fig. 2 Total degradation of chicken feathers observed in crude enzymatic extracts and after exposure to reaction systems. a Control; b Crude; c Concentrated; d K4519 SIGMA commercial enzyme concentrated and stable; nevertheless, it did not degrade the chicken feathers used in the tests.

Swine hair and chicken feathers are part of the group of hard keratins owing to their high concentrations of cysteine, rendering them very resistant (KorniłłowiczKowalska and Bohacz 2011). However, $\alpha$-keratin present in the swine hair structure has large amounts of sulfur, which confers highly resistant mechanical properties (Holkar et al. 2018). This explains why chicken feathers are more easily degraded than swine hair.

In addition, the keratin structure formed by disulfide bonds ensures stability and resistance to enzymatic degradation. Kunert (1989) found that the reduction of disulfide bonds considerably influenced the degradation of keratin structure, ensuring efficient keratin hydrolysis. This suggests that the homemade enzyme extract acted on disulfide bonds and reduced the cystine concentration present in the keratin structure, as well as converting the sulfur molecule into smaller structures (Jaouadi et al. 2013).

However, the exact process of degradation involves a series of mechanisms of action that occur in 3 stages. Mechanical keratinolysis occurs by the action of mycelium-producing fungi, involving the penetration of the mycelium into the keratin residue. Then, the hydrolysis of the disulfide bonds occurs, responsible for ensure the resistance and stability of the keratin structure. Finally, 
proteolysis occurs involving the action of the enzyme itself (Kunert 1989; Onifade et al. 1998).

For the concentrated enzymatic extract, no residue degradation was observed in any of the evaluated extracts. In the tests where there were high values of keratinolytic activity, the degradation percentages were low or almost nonexistent. This agrees with the study by Riffel and Brandelli (2006), where high values for keratinolytic activity were verified; nevertheless, the purified enzyme was not able to degrade chicken feathers. The authors suggest that in these cases, enzymes such as disulfide reductases and proteases need to act so that feather degradation occurs (Fang et al. 2013b).

The presence of inhibitors may explain why there was no residue degradation (Hamiche et al. 2019). Despite the fact that the enzyme is concentrated and the amount of impurities is reduced, it has no potential for degradation of residues (Riffel and Brandelli 2006).

\section{Characterization of homemade keratinase enzymes}

The characterization of homemade keratinases was carried out by evaluating different $\mathrm{pH}$ and temperature conditions in an ultra-thermostatic bath for $1 \mathrm{~h}$. The highest enzyme activity was achieved at $\mathrm{pH} 8.5(50 \mathrm{mM}$ Tris $\mathrm{HCl}$ buffer) and $50{ }^{\circ} \mathrm{C}$ temperature.

Most of keratinases producing microorganisms operate in the neutral and alkaline $\mathrm{pH}$ range, and the degradation of keratin is favored in alkaline $\mathrm{pH}$, with the modification of cysteine residues and making them more accessible for the action of the enzyme. The optimum temperature is in the range of $28{ }^{\circ} \mathrm{C}$ to $50{ }^{\circ} \mathrm{C}$, reaching $70{ }^{\circ} \mathrm{C}$ depending on the microorganism. In addition, most keratinases have good stability over wide $\mathrm{pH}$ and temperature ranges (Anbu et al. 2005).

\section{Conclusion}

Biotechnological processes involving the biodegradation of keratinolytic materials by action of microorganisms and enzymes are promising alternatives to improve the degradability of these materials, thereby adding value to the material. Ultrasonic and microwave reaction systems are viable alternatives for evaluating the behavior of keratinases and the potential for pretreatment of keratinous residues.

The pretreatment in an ultrasonic probe using the macropoint causes greater energy dissipation due to the larger diameter in relation to the micropoint, thus increasing the reaction rates and facilitating the degradation process of the exposed structures due to the propagation of ultrasonic waves, resulting in greater weight loss. Thus, the use of the ultrasonic probe as a pretreatment can be quite useful when looking for greater enzyme production in a shorter time. For longer processes, the use of waste without pretreatment becomes more promising, also decreasing energy expenditure, since the enzymatic activity achieved over time is greater.

Regarding the evaluation of the behavior of keratinases in relation to reaction systems, different behaviors were observed from enzymatic extracts, showing that it is possible to produce enzymes with different characteristics and behaviors. The ultrasonic probe proved to be more promising, generating the greatest increase in enzymatic activity. The enzymatic concentration showed a significant increase in activity, showing that simple and low-cost techniques can be efficient.

It was found that the crude enzymatic extract has the potential to degrade chicken feathers, while the other extracts used did not show potential for degradation, thus making it a very interesting result.

\section{Acknowledgements}

The authors are grateful to the Fundação de Amparo à Pesquisa do Estado do Rio Grande do Sul - FAPERGS, to the Coordenação de Aperfeiçoamento de Pessoal de Nível Superior - CAPES; to the Conselho Nacional de Desenvolvimento Científico e Tecnológico - CNPq; and to the research group at Laboratório de Microbiologia e Bioprocessos - LAMIBI da UFFS campus Erechim.

\section{Authors' contributions}

FFC, SK, KPP, CD, TS, CB, FSS, AFC and JZ: experimental procedures, results discussion, and data treatment AJM, GF, HT: research coordinators. All authors read and approved the final manuscript.

Funding

CAPES, CNPq and FAPERGS.

Availability of data and materials

The datasets generated for this study are available on request to the corresponding author.

\section{Ethics approval and consent to participate}

Not applicable.

\section{Consent for publication}

All authors agreed with this publication.

\section{Competing interests}

There are not competing interests.

\section{Author details}

${ }^{1}$ Laboratory of Microbiology and Bioprocesses, Universidade Federal Da Fronteira Sul-UFFS, Rodovia ERS 135-Km 72, n 200, Erechim, RS 99700-970, Brazil.

${ }^{2}$ Department of Microbiology Immunology and Parasitology, Universidade Federal de Florianópolis-UFSC, Engenheiro Agronômico Andrei Cristian Ferreira St., Trindade, Florianópolis, SC 88040-900, Brazil.

Received: 12 April 2020 Accepted: 18 September 2020

Published online: 26 September 2020

\section{References}

Abdel-Fattah AM, El-Gamal MS, Ismail SA, Emran MA, Hashem AM (2018) Biodegradation of feather waste by keratinase produced from newly isolated Bacillus licheniformis ALW1. J Genet Eng Biotechnol 16:311-318. https:// doi.org/10.1016/j.jgeb.2018.05.005

Anbu P, Gopinath SCB, Hilda A (2005) Purification of keratinase from poultry farm isolate-Scopulariopsis brevicaulis and statistical optimization of 
enzyme activity. Enzyme Microb Technol 36:639-647. https://doi. org/10.1016/j.enzmictec.2004.07.019

ANTON PAAR. Reator de Micro-ondas Monowave 100 ANTON PAAR. Available in: https://www.anton-paar.com/br-pt/produtos/detalhes/sintese-assis tida-por-micro-ondas-monowave-400200/. Accessed 25 May 2018

Azmi NA, Idris A, Yusof NSM (2018) Ultrasonic technology for value added products from feather keratin. Ultrason Sonochem 47:99-107. https://doi. org/10.1016/j.ultsonch.2018.04.016

Barone JR, Schmidt WF, Gregoire NT (2006) Extrusion of Feather Keratin. J Appl Polym Sci 100:1432-1442. https://doi.org/10.1002/app.23501

Barton S, Bullock C, Weir D (1996) The effects of ultrasound on the activities of some glycosidase enzymes of industrial importance. Enzyme Microb Technol 18:190-194. https://doi.org/10.1016/0141-0229(95)00092-5

BIOVERA. PROCESSADOR ULTRASSÔNICO/SONICADOR DE PONTEIRA. 2019. Available in: https://www.biovera.com.br/noticias/saiba-tudo-sobre -processador-ultrassonico-sonicador-de-ponteira-sonicador/. Accessed 25 May 2020

Brandelli A (2008) Bacterial Keratinases: useful Enzymes for Bioprocessing Agroindustrial Wastes and Beyond. Food Bioproc Tech 1:105-116. https:// doi.org/10.1007/s11947-007-0025-y

Brandelli A, Daroit DJ, Riffel A (2010) Biochemical features of microbial keratinases and their production and applications. Appl Environ Microbiol 85:1735-1750. https://doi.org/10.1007/s00253-009-2398-5

Brandelli A, Sala L, Kalil SJ (2015) Microbial enzymes for bioconversion of poultry waste into added-value products. Food Res Int 73:3-12. https:// doi.org/10.1016/j.foodres.2015.01.015

Bressollier P, Letourneau F, Urdaci M, Verneuil B (1999) Purification and characterization of a keratinolytic serine proteinase from Streptomyces albidoflavus. Appl Environ Microbiol 65:2570-2578. https://doi.org/10.1128/ aem.65.6.2570-2576.1999

Călin M, Constantinescu-Aruxandei D, Alexandrescu E, Răut I, Doni MB, Arsene ML, Oancea F, Jecu L, Lazăr V (2017) Degradation of keratin substrates by keratinolytic fungi. Electron J Biotechn 28:101-112. https://doi. org/10.1016/j.ejbt.2017.05.007

Choińska-Pulit A, Łaba W, Rodziewicz A (2019) Enhancement of pig bristles waste bioconversion by inoculum of keratinolytic bacteria during composting. Waste Manage 84:269-276. https://doi.org/10.1016/j.wasma n.2018.11.052

ECO-SONICS. Desruptor de células. Available in: https://www.ecosonics.com. br/produto/20/desruptor-de-celulas. Accessed 02 June 2018

Fang Z, Zhang J, Liu B, Du G, Chen J (2013a) Biodegradation of wool waste and keratinase production in scale-up fermenter with different strategies by Stenotrophomonas maltophilia BBE11-1. Bioresour Technol 140:286-291. https://doi.org/10.1016/j.biortech.2013.04.091

Fang Z, Zhang J, Liu C, Du G, Chen J (2013b) Biochemical characterization of three keratinolytic enzymes from Stenotrophomonas maltophilia BBE11-1 for biodegrading keratin wastes. Int Biodeterior Biodegrad 82:166-172. https://doi.org/10.1016/j.ibiod.2013.03.008

Fegade SL, Tande BM, Cho H, Seames WS, Sakodynskaya I, Muggli DS, Kozliak EI (2013) Aromatization of Propylene over HZSM-5: a Design of Experiments (DOE) approach. Chem Eng Commun 200(8):1039-1056. https://doi. org/10.1080/00986445.2012.737385

Feng H, Barbosa-Cánovas GV, Weiss J (eds) (2011) Ultrasound technologies for food and bioprocessing. Springer, New York

Gegeckas A, Šimkutè A, Gudiukaitè R, Čitavičius DJ (2018) Characterization and application of keratinolytic paptidases from Bacillus spp. Int J Biol Macromol 113:1206-1213. https://doi.org/10.1016/j.ijbiomac.2018.03.046

Golunski S M, Scapini T, Modkovski T A, Marques C T, Camargo A F, Preczeski K P, Dalla Rosa C, Baldissarelli D P, Mulinari J, Venturin B, Vargas G D L P, Buffon J G, Mossi A J, Treichel H (2017) Commercial and Noncommercial Peroxidases Activity under Ultrasound and Microwave Treatment: a Pretreatment to Improve Wastewater Treatment. J Braz Chem Soc 28: 1890-1895. https://doi.org/10.21577/0103-5053.20170023

Grintsevich EE, Adzerikho IE, Mrochek AG, Metelitza DI (2001) Polydisulfides of substituted phenols as effective protectors of peroxidase against inactivation by ultrasonic cavitation. Biochemistry 66:740-746. https:// doi.org/10.1023/a:1010256511200

Gupta R, Ramnani P (2006) Microbial keratinases and their prospective applications: an overview. Appl Environ Microbiol 70:21-33. https://doi. org/10.1007/s00253-005-0239-8
Hamiche S, Mechri S, Khelouia L, Annane R, El Hattab M, Badis A, Jaouadi B (2019) Purification and biochemical characterization of two keratinases from Bacillus amyloliquefaciens S13 isolated from marine brown alga Zonaria tournefortii with potential keratin-biodegradation and hide-unhairing activities. Int J Biol Macromol 122:758-769. https://doi.org/10.1016/j.ijbio mac.2018.10.174

Holkar CR, Jain SS, Jadhav AJ, Pinjari DV (2018) Valorization of keratin waste. Process Saf Environ 115:85-98. https://doi.org/10.1016/j.psep.2017.08.045

Ire FS, Onyenama AC (2017) Effects of Some Cultural Conditions on Keratinase Production by Bacillus licheniformis Strain NBRC 14206. J Adv Biol Biotechnol 13:1-13. https://doi.org/10.9734/jabb/2017/32726

Jaouadi NZ, Rekik H, Badis A, Trabelsi S, Belhoul M, Yahiaoui AB, Aicha HB, Toumi A, Bejar S, Jaouadi B (2013) Biochemical and molecular characterization of a serine keratinase from Brevibacillus brevis US575 with promising keratin-biodegradation and hide-dehairing activities. PLOS ONE 8:1-17. https://doi.org/10.1371/journal.pone.0076722

Jin J, Ma H, Qu W, Wang K, Zhou C, He R, Luo L, Owusu J (2015) Effects of multifrequency power ultrasound on the enzymolysis of corn gluten meal: kinetics and thermodynamics study. Ultrason Sonochem 27:46-53. https ://doi.org/10.1016/j.ultsonch.2015.04.031

Kapturowska AU, Stolarzewicz IA, Krzyczkowska J (2012) Studies on the lipolytic activity of sonicated enzymes from Yarrowia lipolytica. Ultrason Sonochem 19:186-191. https://doi.org/10.1016/j.ultsonch.2011.06.015

Kaul S, Sumbali G (1997) Keratinolysis by poultry farm soil fungi. Mycopathologia 139:137-140. https://doi.org/10.1023/a:1006896030739

Khan NR, Rathod VK (2018) Microwave assisted enzymatic synthesis of speciality esters: a mini - review. Process Biochem 75:89-98. https://doi. org/10.1016/j.procbio.2018.08.019

Korniłłowicz-Kowalska T, Bohacz J (2011) Biodegradation of keratin waste: theory and practical aspects. Waste Manage 31:1689-1701. https://doi. org/10.1016/j.wasman.2011.03.02

Kothari D, Rani A, Goyal A (2017) Keratinases. In: Pandey A, Negi S, Soccol C R (ed) Current Developments in Biotechnology and Bioengineering: Production, Isolation and Purification of Industrial Products, $1^{\circ}$ edn. Elsevier. doi: https://doi.org/10.1016/B978-0-444-63662-1.00019-1

Kuijpers MWA, Kemmere MF, Keurentjes JTF (2002) Calorimetric study of the energy efficiency for ultrasound-induced radical formation. Ultrasonics 40:675-678. https://doi.org/10.1016/s0041-624x(02)00197-x

Kunert K (1989) Biochemical mechanism of keratin degradation by the actinomycete Streptomyces fradiae and the fungus Microsporum gypseum: a comparison. J Basic Microbiol 29:597-604. https://doi.org/10.1002/ jobm.3620290909

Kushwaha RKS (1983) The In Vitro Degradation of Peacock Feathers by Some Fungi. Mykosen 26:324-326. https://doi.org/10.1111/j.1439-0507.1983. tb03218.x

Łaba W, Kopeć W, Chorążyk D, Kancelista A (2015) Biodegradation of pretreated pig bristles by Bacillus cereus B5esz. Int Biodeterior Biodegrad 100:116-123. https://doi.org/10.1016/j.ibiod.2015.02.024

Leaes EX, Lima D, Miklasevicius L, Ramon AP, Dal Prá V, Bassaco MM, Terra LM, Mazutti MA (2013) Effect of ultrasound-assisted irradiation on the activities of a-amylase and amyloglucosidase. Biocatal Agric Biotechnol 2:21-25. https://doi.org/10.1016/j.bcab.2012.08.003

Leonelli C, Mason TJ (2010) Microwave and ultrasonic processing: now a realistic option for industry. Chem Eng Process 49:885-900. https://doi. org/10.1016/j.cep.2010.05.006

Lippert T, Bandelin J, Musch A, Drewes JE, Koch K (2018) Energy-positive sewage sludge pre-treatment with a novel ultrasonic flatbed reactor at low energy input. Bioresour Technol 264:298-305. https://doi.org/10.1016/j. biortech.2018.05.073

Lopes LC, Barreto MTM, Gonçalves KM, Alvarez HM, Heredia MF, Souza ROMA, Cordeiro Y, Dariva C, Fricks AT (2015) Stability and structural changes of horseradish peroxidase: microwave versus conventional heating treatment. Enzyme Microb Technol 69:10-18. https://doi.org/10.1016/j.enzmi ctec.2014.11.002

Ma H, Huang L, Jia J, He R, Luo L, Zhu W (2011) Effect of energy-gathered ultrasound on Alcalase. Ultrason Sonochem 18:419-424. https://doi. org/10.1016/j.ultsonch.2010.07.014

Manasseh R, Tho P, Ooi A, Petrovic-Duran K, Zhu Y (2010) Cavitation microstreaming and material transport around microbubbles. Phys Procedia 3:427-432. https://doi.org/10.1016/j.phpro.2010.01.056 
Mason TJ, Cobley AJ, Graves JE, Morgan D (2011) New evidence for the inverse dependence of mechanical and chemical effects on the frequency of ultrasound. Ultrason Sonochem 18:226-230. https://doi.org/10.1016/j. ultsonch.2010.05.008

Mazinani SA, DeLong B, Yan H (2015) Microwave radiation accelerates trypsincatalyzed peptide hydrolysis at constant bulk temperature. Tetrahedron Lett 56:5804-5807. https://doi.org/10.1016/j.tetlet.2015.09.003

Mazotto AM, Melo ACN, Macrae A, Rosado AS, Peixoto R, Cedrola SML, Couri S, Zingali RB, Villa ALV, Rabinovitch L, Chaves JQ, Vermelho AB (2011) Biodegradation of feather waste by extracellular keratinases and gelatinases from Bacillus spp. World J Microbiol Biotechnol 27:1355-1365. https://doi. org/10.1007/s11274-010-0586-1

Mazotto AM, Couri S, Damaso MCT, Vermelho AB (2013) Degradation of feather waste by Aspergillus niger keratinases: comparison of submerged and solid-state fermentation. Int Biodeterior Biodegrad 85:189-195. https ://doi.org/10.1016/j.ibiod.2013.07.003

McClements DJ (1995) Advances in the application of ultrasound in food analysis and processing. Trends Food Sci Tech 6:293-299. https://doi. org/10.1016/s0924-2244(00)89139-6

Mulinari J, Venturin B, Sbardelotto M, Dall Agnol A, Scapini T, Camargo AF, Baldissarelli DP, Modkovski TA, Rossetto V, Dalla Rosa C, Reichert FW Jr, Golunski SM, Vargas GDLP, Dalla Rosa C, Mossi AJ, Treichel H (2017) Ultrasound-assisted hydrolysis of waste cooking oil catalyzed by homemade lipases. Ultrason Sonochem 35:313-318. https://doi.org/10.1016/j. ultsonch.2016.10.007

Okoroma EA, Garelick H, Abiola OO, Purchase D (2012) Identification and characterisation of a Bacillus licheniformis strain with profound keratinase activity for degradation of melanised feather. Int Biodeterior Biodegrad 74:54-60. https://doi.org/10.1016/j.ibiod.2012.07.013

Onifade AA, Al-Sane NA, Al-Musallam AA, Al-Zarban S (1998) A Review: potentials for biotechnological applications of keratin-degrading microorganisms and their enzymes for nutritional improvement of feathers and other keratins as livestock feed resources. Bioresour Technol 66:1-11. https://doi.org/10.1016/s0960-8524(98)00033-9

Ovsianko SL, Chernyavsky EA, Minchenya VT, Adzerikho IE, Shkumatov VM (2005) Effect of ultrasound on activation of serine proteases precursors. Ultrason Sonochem 12:219-223. https://doi.org/10.1016/j.ultso nch.2003.10.012

Paul T, Das A, Mandal A, Halder SK, Jana A, Maity C, Das Mohapatra PK, Pati BR, Mondal KC (2014) An efficient cloth cleaning property of a crude keratinase combined with detergent: towards industrial viewpoint. J Clean Prod 66:672-684. https://doi.org/10.1016/j.jclepro.2013.10.054

Potapovich MV, Eremin AN, Metelitza DI (2003) Kinetics of Catalase Inactivation Induced by Ultrasonic Cavitation. Appl Biochem Micro 39:140-146. https ://doi.org/10.1023/a:1022577611056

Preczeski K P, Dalastra C, Czapela F F, Kubeneck S, Scapini T, Camargo A F, Zanivan J, Bonatto C, Stefanski F S, Venturin B, Fongaro G, Treichel H (2020) Fusarium oxysporum and Aspergillus sp. as keratinase producers using swine hair from agroindustrial residues. Fronti Bioeng Biotech. https://doi. org/10.3389/fbioe.2020.00071

Preczeski KP, Kamanski AB, Scapini T, Camargo AF, Modkoski TA, Rossetto V, Venturin B, Mulinari J, Golunski SM, Mossi AJ, Treichel H (2018) Efficient and low-cost alternative of lipase concentrating aiming at the application in the treatment of waste cooking oils. Bioprocess Biosyst Eng 41:851-857. https://doi.org/10.1007/s00449-018-1919-y

Resa P, Elvira L, Sierra C, Espinosa FM (2009) Ultrasonic velocity assay of extracellular invertase in living yeasts. Anal Biochem 384:68-73. https://doi. org/10.1016/j.ab.2008.09.025
Riffel A, Brandelli A (2006) Keratinolytic bacteria isolated from feather waste. Braz J Microbiol 37:395-399. https://doi.org/10.1590/s1517-8382200600 0300036

Rodrigues M I, lemma A F (2014) Protimiza Experimental Design. Available in: http://experimental-design.protimiza.com.br/. Accessed 10 January 2019

Santos RMDB, Firmino AAP, Sá CM, Felix CR (1996) Keratinolytic Activity of Aspergillus fumigatus Fresenius. Curr Microbiol 33:364-370. https://doi. org/10.1007/s002849900129

Scott JA, Untereiner WA (2004) Determination of keratin keratin degradation by fungi using keratin azure. Med Mycol J 42:239-246. https://doi. org/10.1080/13693780310001644680

SIGMA-ALDRICH. K4519 SIGMA Keratinase. Available in: https://www.sigma aldrich.com/catalog/product/sigma/k4519?lang=pt\&region=BR>. Accessed 28 May 2018

Su C, Gong J, Zhang R, Tao L, Dou W, Zhang D, Li H, Lu Z, Xu Z, Shi J (2017) A novel alkaline surfactant-stable keratinase with superior feather-degrading potential based on library screening strategy. Int J Biol Macromol 95:404-411. https://doi.org/10.1016/j.ijbiomac.2016.11.045

Thankaswamy SR, Sundaramoorthy S, Palanivel S, Ramudu KN (2018) Improved microbial degradation of animal hair waste from leather industry using Brevibacterium luteolum (MTCC 5982). J Clean Prod 189:701-708. https:// doi.org/10.1016/j.jclepro.2018.04.095

Wang LC (1981) Soybean Protein Agglomeration: promotion by Ultrasonic Treatment. J Agr Food Chem 29:177-180. https://doi.org/10.1021/ff001 03 a044

Wang J, Yanping C, Sun B, Wang C, Mo Y (2011) Effect of ultrasound on the activity of alliinase from fresh garlic. Ultrason Sonochem 18:534-540. https://doi.org/10.1016/j.ultsonch.2010.09.008

Wang F, Chen Z, Zhu H (2013) An efficient enzymatic modification of lily polysaccharide in ionic liquid under ultrasonic irradiation. Biochem Eng J 79:25-28. https://doi.org/10.1016/j.bej.2013.06.020

Yadav GD, Borkar IV (2009) Kinetic and mechanistic investigation of microwave-assisted lipase catalyzed synthesis of citronellyl acetate. Ind Eng Chem Res 48:7915-7922. https://doi.org/10.1021/ie800591c

Yang C, Fang TJ (2015) Kinetics for enzymatic hydrolysis of rice hulls by the ultrasonic pretreatment with a bio-based basic ionic liquid. Biochem Eng J 100:23-29. https://doi.org/10.1016/j.bej.2015.04.012

Yusof NSM, Ashokkumar M (2015) Sonochemical synthesis of gold nanoparticles by using high intensity focused ultrasound. ChemPhysChem 16:775-781. https://doi.org/10.1002/cphc.201402697

Yusuf I, Ahmad SA, Phang LY, Syed MA, Shamaan NA, Khalii KA, Dahalan FA, Shukor MY (2016) Keratinase production and biodegradation of polluted secondary chicken feather wastes by a newly isolated multi heavy metal tolerant bacterium-Alcaligenes sp. AQ05-001. J Environ Manage 183:182-195. https://doi.org/10.1016/j.jenvman.2016.08.059

Zou S, Wang X, Chen Y, Wan H, Feng Y (2016) Enhancement of biogas production in anaerobic co-digestion by ultrasonic pretreatment. Energ Convers Manage 112:226-235. https://doi.org/10.1016/j.enconman.2015.12.087

\section{Publisher's Note}

Springer Nature remains neutral with regard to jurisdictional claims in published maps and institutional affiliations. 